\title{
Organization of the Information Flows in Company Management in the Context of Digitalization
}

\author{
Horoshilov D.N.* \\ Voronezh State Technical University \\ Voronezh, Russia \\ e-mail: horoshilov3@yandex.ru \\ Krasnikova A.V. \\ Voronezh State Technical University \\ Voronezh, Russia \\ e-mail: anna-solomka@yandex.ru \\ Rybkina O.V. \\ Voronezh State Technical University \\ Voronezh, Russia \\ e-mail: ryzhunya@inbox.ru
}

\author{
Enina E.P. \\ Voronezh State Technical University \\ Voronezh, Russia \\ e-mail: anclesashas@yandex.ru \\ Milovanova N.S. \\ Voronezh State Technical University \\ Voronezh, Russia \\ e-mail: natasha.11061977m@gmail.com \\ Kranov S.E. \\ Voronezh State Technical University \\ Voronezh, Russia \\ e-mail: sergkranov@bk.ru
}

\begin{abstract}
The article describes the structure of information flows in company management based on the development of innovative potential and in the context of digitalization. The scheme of moving the project groups of the company management system is presented. A matrix of managerial relationships between the participants of the company management system is built taking into account the development of the innovative potential. It is concluded that at an industrial enterprise without the introduction of digitalization, the information flow running is impeded, which significantly affects the quality and speed of management decisions. The main reasons for the ineffectiveness of management decisions are identified. Given the possible ways to improve management efficiency in the context of digitalization, the authors developed a model of information flows of the company management system that implements innovative potential. Calculations are made of the time required to quickly transfer a managerial decision from the upper management level to the lower one, so that the top-level manager quickly learns about any changes that have occurred in the system. It is concluded that it is necessary to provide a single information space for all participants in the company management system in the context of digitalization, reducing the time spent on information exchange to almost zero. The authors summarized the research with the concept that the construction of a single company management information system can significantly reduce the time for the transfer of managerial decisions due to the fact that the participants in the management chain can perform their work in parallel. When developing the architecture of a company's management information system and choosing a structure for its construction, it is necessary to take into account exactly which time commitments have the key impact on the length of management decision-making in the context of digitalization.
\end{abstract} flows.

Keywords - digitalization, company management, information

\section{INTRODUCTION}

In the context of the implementation of programs for the innovative potential development between the blocks of the management structure, a complex system of managerial relations arises. The complexity of this kind of relationship is caused by the features of the matrix (staff) structure and, in our opinion, consists in the need to streamline the types of relationships among the project participants. For this purpose, it is possible to conditionally classify managerial relations into the following groups: relations of linear management, functional management; staff leadership, relationship of collaboration, relationship of information interaction $[5,7]$.

Such relations require prescription in the department regulations, job descriptions, and other organizational and administrative documents, which clearly reflect the rights and responsibilities in all respects regarding the work performed and the links between the blocks.

\section{MATERIALS AND METHODS}

A scheme has been developed for moving individual project teams as part of a company management system based on the innovative potential development. The coordinator of the project for the innovative potential development of the company in the context of digitalization acts as the core of the project management. He interacts with the project groups:

- the project group for the development of industrial and technology potential;

- the project group for the development of financial potential;

- the project group for the development of scientific and research potential; 
- the project group for the development of information and procedural potential;

- the project group for the development of marketing potential;

- the project group for the development of organizational and managerial potential;

- the project group for the development of human resource potential.
A matrix of relations between the pairs of interacting blocks of the company management system based on the innovative potential development has been developed. In each pair of the presented units there can be one of the following types of interactions: linear (L), staff $(\mathrm{S})$, functional $(\mathrm{F})$, procedural $(\mathrm{P})$ management, as well as technical interaction (T) and collaboration (C) (table 1).

TABLE I. THE MATRIX OF MANAGERIAL RELATIONSHIPS AMONG THE PARTICIPANTS OF THE COMPANY'S MANAGEMENT SYSTEM BASED ON THE INNOVATIVE POTENTIAL DEVELOPMENT

\begin{tabular}{|c|c|c|c|c|c|c|c|}
\hline Units & $\begin{array}{c}\text { Deputy } \\
\text { director for } \\
\text { science and } \\
\text { innovation }\end{array}$ & $\begin{array}{c}\text { Corporate } \\
\text { management } \\
\text { unit }\end{array}$ & $\begin{array}{c}\text { Functional } \\
\text { managers }\end{array}$ & Consultants & $\begin{array}{c}\text { Data } \\
\text { processing } \\
\text { computer } \\
\text { center }\end{array}$ & $\begin{array}{c}\text { Economic } \\
\text { planning unit }\end{array}$ & Other units \\
\hline $\begin{array}{l}\text { Deputy director for science } \\
\text { and innovation }\end{array}$ & & $\mathrm{Lc}$ & $\mathrm{Lc}$ & $\mathrm{C}, \mathrm{Tp}$ & Lc & $\mathrm{Fc}, \mathrm{Sc}$ & $\mathrm{Fc}$ \\
\hline Corporate management unit & Ls & & Ss, Fs & Ps, C & $\mathrm{Tr}, \mathrm{C}$ & $\mathrm{Sc}, \mathrm{Pc}$ & $\mathrm{Tp}, \mathrm{Pc}, \mathrm{C}$ \\
\hline Functional managers & Ls & $\mathrm{Sc}, \mathrm{Fc}$ & & $\mathrm{C}, \mathrm{Ps}$ & $\mathrm{Tr}, \mathrm{Sc}$ & $\mathrm{C}$ & Sc, C \\
\hline Consultants & $\mathrm{C}, \mathrm{Tr}$ & $\mathrm{Pc}, \mathrm{C}$ & $\mathrm{C}, \mathrm{Pc}$ & & $\mathrm{C}$ & $\mathrm{C}$ & $\mathrm{C}$ \\
\hline $\begin{array}{l}\text { Data processing computer } \\
\text { center }\end{array}$ & Ls & $\mathrm{Tp}, \mathrm{C}$ & Tp, Ss & $\mathrm{C}$ & & Fs, Tp & Fs, Tp \\
\hline Economic planning unit & Fs, Ss & Ss, Ps & $\mathrm{C}$ & $\mathrm{C}$ & $\mathrm{Fc}, \mathrm{Tr}$ & & $\mathrm{C}$ \\
\hline Other units & Fs & Tr, Ps, C & Ss, C & $\mathrm{C}$ & $\mathrm{Fc}, \mathrm{Tr}$ & $\mathrm{C}$ & \\
\hline
\end{tabular}

So, based on the presented matrix, if a pair of blocks is in a managerial relationship, then, one of the blocks is controlling the other $(\mathrm{C})$, while the other is subordinate $(\mathrm{S})$. Thus, every type of managerial relationships can be classified as follows: Lc and Ls, Sc and Ss, Fc and Fs, Pc and Ps. The absence in the organizational process of any of the listed components indicates a defect in the organizational structure [2].

Along with the relationship of management, it is also necessary to highlight the relationship of collaboration (C), suggesting the transfer of some information or work results from one block to another. In relation to the developed organizational structure, such type of relationship is characteristic primarily of the relations with an outside consultant.

The technical interaction relationships suggest, on one hand, provision of works and services of technical nature, and on the other hand, receiving and consumption of such works, services, and resources (Tp, Tr).

The presented matrix allows assessing the state of relations in the organization's structure for development management, timely detecting and eliminating possible "imbalances" and job inconsistencies.

The detail analysis of this matrix helps to detect the following types of defects $[10,4]$ :

(i) a pair of blocks is connected by linear relationships, therefore, one of the blocks should be marked with Lc, the other Ls. Its absence causes a defect in the relationship. That means the task can be realized with the least losses if both conditions are met: Lc and Ls;

(ii) the same can be observed in the relations of procedural guidance and technical interaction: if one block receives procedural or technical services, or certain resources, then the responsibility for their transfer falls on the other block.

The analysis of the existing organizational structure of management and the scheme of information flows shows that, despite the restructuring and generally correctly selected organizational structure, the information flow running is impeded, which in turn affects the quality and speed of management [6].

The key reasons for ineffective management decisions in the absence of digitalization of a company are the following:

- lack of the uniform standards for accounting, monitoring, and of the single information base for all participants in the innovation process, which increases the time of the information flow running due to the need to «dock» different information processing systems;

- use for coordination of many different regulations, the number of which is growing in a geocentric progression, which creates an «information mess»;

- fragmented functions in various departments, which complicates the passage of information flows, causing a delay in the management decision-making;

- ignoring the effects of the socionomy factor on the passage of the information flow, by shifting the emphasis of staff from performing professional tasks to clarifying interpersonal relationships;

- the need for numerous unnecessary movement of employees;

- excessive control over the innovative unit's performance from the part of the management; 
- paper documents, quite avoidable [2, 8].

To eliminate the above listed reasons, we build a tree of goals and objectives for the integrated management of all streaming information processes in the logistics information system (Figure 01).

The authors propose a scheme for the phased implementation of the logistic approach to the organization of information flows in the company management.

In the proposed organizational structure of the information flows in the company management system, based on the development of innovative potential and digitalization, the information flows are clearly streamlined by applying modern information technologies and implementing ERP management systems, which in turn will allow one to [9]:

- $\quad$ speed up the process of data transfer from one unit to another;

- clearly adjust the transfer of the input information and the feedback;

- $\quad$ speed up the process of managerial decision-making;

- adjust the functional duties of each unit;

- delete excessive control over the innovative unit's performance with still keeping coordinating their operation $[3,11]$;
- direct the freed up reserve of labor time to increase the innovative potential.

There are three groups of employees in any company management system, who are involved in the process of managing its implementation. First of all, they are the top management, i.e. specialists responsible for setting goals and objectives, integrated planning of the organization and assessing the implementation of these plans. Secondly, they are specialists responsible for developing detailed plans for achieving the goals set by the top management; the distribution of work by specific performers, planning the use of resources, monitoring the implementation of plans, and preparing aggregated reports for the top management. And finally, they are the field staff responsible for the performance of certain work in accordance with the schedule, reporting on the status of the work performed, its quality, availability, and resource loading [12, 2].

In addition to the deputy director for innovative potential development himself, who is the executor (organizer) of the company's innovative potential development project, almost all departments of the company, including functional managers, also participate in its implementation. The list of the participants will vary from project to project, but these levels of management will be present to solve the above tasks for the innovative potential development.

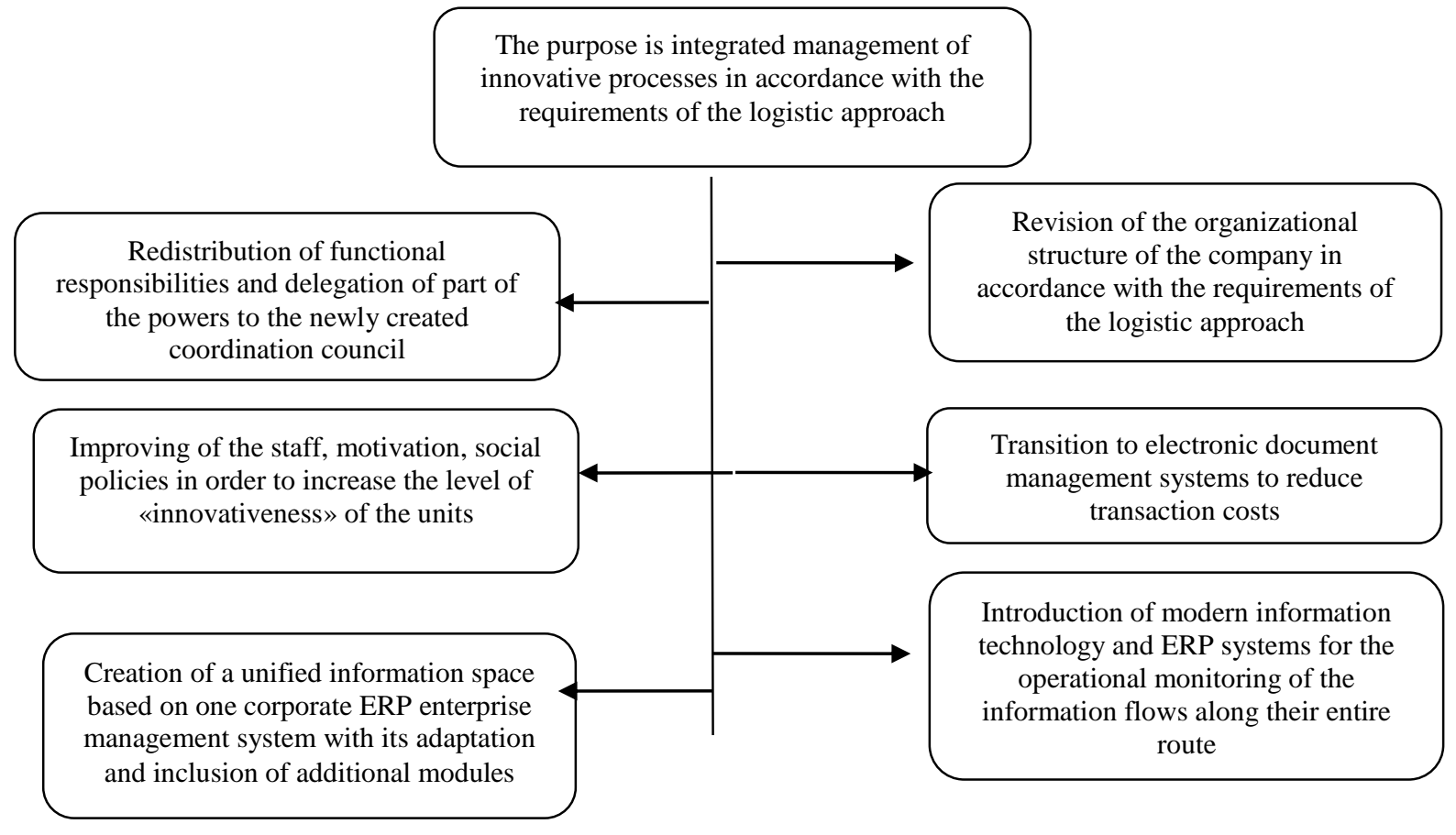

Fig. 1. The tree of goals and objectives for the integrated management of streaming information processes in a company management system

The project involves numerous interrelated activities. Therefore, it depends on the coordinated actions of all its participants whether it will be successful or not. But the organization of coordinated work requires a constant exchange of information between different levels of management, not only vertically in the management hierarchy, but also horizontally $[8,15]$. 


\section{DisCUSSION AND RESULTS}

The authors propose a model of information flows of a company management system that implements innovative potential in the context of digitalization (figure 2).

The model is based on time for processing and exchange of the information between all participants in the management chain. Below the calculations of the time required for the decision made at the upper management level to reach the lower one are demonstrated, as well as for the top-level manager to know about changes that have occurred in the system $[13,4]$.
To simplify the model, we assume that when processing information at one control level, data is not exchanged with any other level. The time required to process information at each of the control levels is:

$$
\mathrm{T}^{\prime}=\mathrm{nt} 0+(\mathrm{n}(\mathrm{n}-1) / 2) \mathrm{t} 1
$$

where t0 - time for initial input and processing of information; $\mathrm{t} 1$ - time for coordination of the operation of several groups; $\mathrm{n}$ - the number of groups participating in the project work at each control level; $n(n-1) / 2$ - the number of the group pairs exchanging with information.

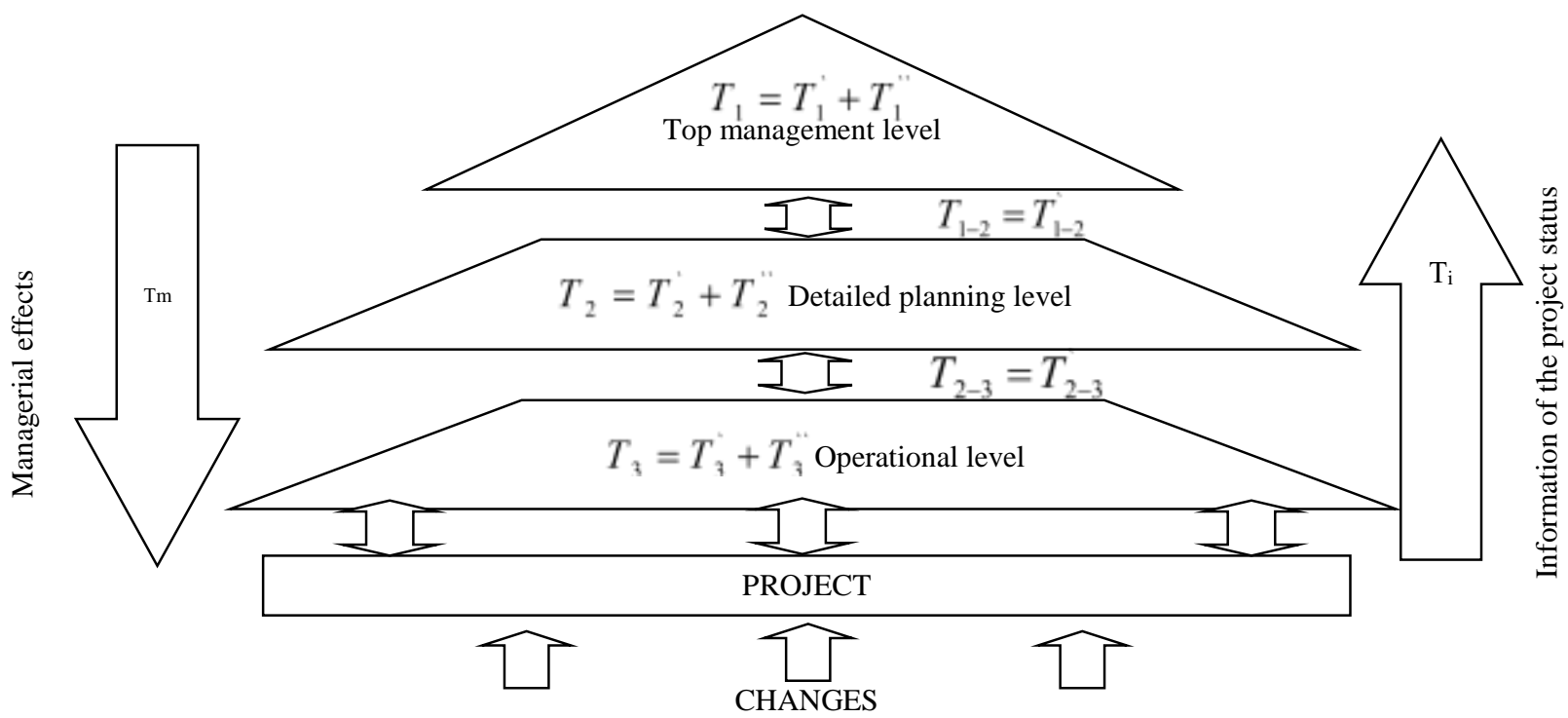

Fig. 2. The model of the information flows in a company management system

The time required for the exchange of information within one control level and the transfer of information between two adjacent levels is:

$$
T^{\prime \prime}=(n(n-1) / 2)(t 2+t 3)
$$

where $\mathrm{t} 2$ - time for information transfer; $\mathrm{t} 3$ - time for repeated input of the same data and for detection of the mistakes in this process.

The time required to prepare information for transfer to the next control level is:

$$
\mathrm{T}=\mathrm{T}^{\prime}+\mathrm{T}^{\prime \prime}
$$

Time required to transfer the information between two adjacent control levels:

$$
\mathrm{T}=\mathrm{T}^{\prime \prime} \text {. }
$$

The time required for the decision made at the upper control level to reach the lower level is:

$$
\begin{gathered}
\text { Ty }=\mathrm{T} 1+\mathrm{T}^{\prime \prime} 1-2+\mathrm{T} 2+\mathrm{T} " 2-3= \\
\left(\mathrm{T}^{\prime} 1+\mathrm{T}^{\prime} 2\right)+\left(\mathrm{T}^{\prime \prime} 1+\mathrm{T}^{\prime \prime} 1-2++\mathrm{T}^{\prime \prime} 2+\mathrm{T}^{\prime \prime} 2-3\right) .
\end{gathered}
$$

The time required for the top-level manager to learn about the changes that have occurred in the project:

$$
\text { Ти }=\mathrm{T} 3+\mathrm{T} " 2-3+\mathrm{T} 2+\mathrm{T} " 1-2=
$$$$
\left(T^{\prime} 3+T^{\prime} 2\right)+\left(T^{\prime \prime} 3+T^{\prime \prime} 2-3++T^{\prime \prime} 2+T^{\prime \prime} 1-2\right)
$$

As can be seen from the above formulas, only two terms make up the useful time expenditures, and four are the expenditures for exchanging information.

This allows one to provide the single information space for all participants in the control system, reducing to almost zero the time spent on information exchange. In addition, it also reduces the time necessary for the top-level manager to learn about the changes that have occurred in the system, because this information becomes available to all interested parties immediately after it is put in at a lower level.

In such a control system, the time required for a decision made at the upper control level to reach the lower level is:

$$
\mathrm{Tm}=\mathrm{T}^{\prime} 1+\mathrm{T}^{\prime} 2,
$$

and the time required for the feedback is:

$$
\mathrm{Ti}=\mathrm{T}^{\prime} 3 .
$$


Modern companies in the context of digitalization reduce both the time for information exchange and the time for its processing, but each structural element has an impact in a certain area (table 02).

TABLE II. THE INFLUENCE OF THE STRUCTURAL ELEMENTS OF THE COMPANY MANAGEMENT SYSTEM ON THE REDUCTION OF THE TIME REQUIRED FOR INFORMATION PROCESSING AND TRANSFER

\begin{tabular}{|c|c|c|c|c|c|c|c|c|}
\hline \multirow[b]{2}{*}{ Structural element of the information system } & \multicolumn{8}{|c|}{ Time } \\
\hline & $T_{1}^{\prime}$ & $T_{1}^{\prime \prime}$ & $T_{1-2}^{\prime \prime}$ & $T_{2}^{\prime}$ & $T_{2}^{\prime \prime}$ & $T_{2-3}^{\prime \prime}$ & $T_{3}^{\prime}$ & $T_{3}^{\prime \prime}$ \\
\hline Professional dairy and network planning systems & & & \multirow{2}{*}{$\bullet * *$} & $\otimes$ & $\bullet *$ & \multirow{2}{*}{$\bullet * *$} & & \\
\hline Low level dairy and network planning systems & $\otimes$ & $\bullet *$ & & & & & $\otimes$ & $\bullet *$ \\
\hline Means for updating the project data through e-mail (off-line)*** & & & & $\otimes$ & $\bullet$ & $\bullet$ & $\otimes$ & \\
\hline Means for publishing the project data through the website*** & $\otimes$ & $\bullet$ & $\bullet$ & $\otimes$ & $\bullet$ & $\bullet$ & $\otimes$ & $\bullet$ \\
\hline $\begin{array}{l}\text { Means for particular tasks (pre-project analysis, budget development, risk } \\
\text { analysis, contract management, time management, etc.) }\end{array}$ & $\otimes$ & $\bullet *$ & & $\otimes$ & $\bullet *$ & & $\otimes$ & $\bullet$ \\
\hline Means for simplified access to the project data & $\otimes$ & $\bullet$ & $\bullet$ & $\otimes$ & $\bullet$ & $\bullet$ & $\otimes$ & $\bullet$ \\
\hline Means for organization of the communications & & $\bullet$ & $\bullet$ & & $\bullet$ & $\bullet$ & & $\bullet$ \\
\hline Integration means & $\otimes$ & $\bullet$ & $\bullet$ & $\otimes$ & $\bullet$ & $\bullet$ & $\otimes$ & $\bullet$ \\
\hline
\end{tabular}

a. Legend: $\otimes$-reduces the time for initial input and processing of information $\left(\mathrm{t}_{0}\right)$;

b. - reduces the time for information transfer $\left(\mathrm{t}_{2}\right)$

c. - reduces the time for information transfer $\left(\mathrm{t}_{2}\right)$ and eliminates the need for repeated entry of the same data $\left(\mathrm{t}_{3}\right)$.

d. *) Network systems only.

e. **) In case of integration of various level dairy and network planning systems.

f. ***) Parts of the dairy and network planning systems.

\section{CONCLUSION}

Summarizing the above, it should be noted that the construction of a single information system for the company management can significantly reduce the time for the transfer of management decisions precisely due to the fact that the participants in the management chain can perform work in parallel and, very importantly, in coordination, without increasing the time spent on information exchange. Therefore, when developing the architecture of a company management information system and choosing the structure for its construction, it is necessary to take into account exactly what time expenditures have the key impact on the duration of management decision-making in the context of digitalization $[13,14]$.

\section{References}

[1] A.V. Ignatieva, M.M. Maksimtsov, "Research of control systems", UNITY-DANA, p. 157, 2007.

[2] A.A. Kulinich, "Cognitive decision support system "Canva"”, Software products and syst., p. 33, 2007.

[3] E.I. Krylov, I.V. Zhuravkova, "Analysis of the efficiency of investment and innovation activities of the enterprise", Finance and statistics, p. 382, 2006.

[4] V.I. Maksimov, E.K. Kornoushenko, S.V. Kachaev, Cognitive technologies for supporting managerial decision-making. Retrieved from: http://www.iis.ru/events/19981130/maximov.ru.html (accessed 10.01.2020).

[5] F.S. Roberts, "Discrete mathematical models with applications to social, biological and environmental problems", Nauka, p. 248, 1986.
[6] B. Twiss, "Management of scientific and technical innovations", Econ., p. $380,1989$.

[7] E.A. Trachtengerz, "Computer support for decision-making", SINTEG, p. 416, 2008.

[8] G.V. Belyaeva, R.V. Nuzhdin, N.I. Ponomareva, E.A. Savvina T.D. Artemenko, "Information and instrumental support of business analysis procedures", Vest. VGUIT, vol. 3, no. 81, pp. 299-300, 2019.

[9] A.V. Shishov, Digitalization of management and production processes of the final product, goals, tasks, problems and ways to solve them. Retrieved from: https://soyuzmash.ru/docs/prez/prez-kstr-020818-1.pdf (accessed 12.01.2020).

[10] Yu.A. Salikov, I.V. Logunova, I.V. Kablashova, "Trends of changes in enterprise human resource management in the digital economy", Vest. VGUIT, vol. 2, no. 80, pp. 393-399, 2019.

[11] I.N. Kosareva "Application of innovative enterprise managemen technologies in the conditions of digitalization", Fundamental research. vol. 6, pp. 73-78, 2019.

[12] Kosareva I.N., Samarina V.P. Features of enterprise management in the conditions of digitalization. Retrieved from: https://cyberleninka.ru/article/n/osobennosti-upravleniya-predpriyatiemv-usloviyah-tsifrovizatsii (accessed 15.01.2020).

[13] F. Bénaben, A "Formal Framework for Crisis Management Describing Information Flows and Functional Structure", Proc. Engineer., vol. 159, pp. 353-356, 2016.

[14] C. Riggle, G. Made, "An analysis of the impact of chaotic dynamics on management information flow models", Europ. J. of Operat. Res., vol. 103, no. 116, pp. 242-254, 1997.

[15] Ch. Barmeyer, U. Mayrhofer, K. Würfl, "Informal information flows in organizations: The role of the Italian coffee break", Int. Busin. Rev., vol. 28 , no. 4, pp. 796-801, 2019. 